Note

\title{
ESTIMATION OF JUNDIÁ (Rhamdia quelen) DIETARY AMINO ACID REQUIREMENTS BASED ON MUSCLE AMINO ACID COMPOSITION
}

\author{
Gustavo Meyer; Débora Machado Fracalossi* \\ UFSC - Depto. de Aqüicultura, Lab. de Biologia e Cultivo de Peixes de Água Doce, C.P. 476 - 88040-900 - \\ Florianópolis, SC - Brasil. \\ *Corresponding author <deboraf@cca.ufsc.br>
}

\begin{abstract}
Jundiá, Rhamdia quelen (Quoy \& Gaimard, 1824), is a catfish native to Central and South America. The species has a number of excellent farming features, such as easy handling, low temperature resistance, efficient feed conversion, flavorsome meat and absence of intramuscular bones, and has been increasingly raised in Southern Brazil. However, most of its nutritional requirements have not yet been determined, including the essential amino acid (EAA) requirements. The objective of the present study was to estimate such requirements through the determination of muscle tissue amino acid composition for four groups of jundiá. Two groups were wild caught and allocated in two categories: from 1 to $100 \mathrm{~g}$ and from 101 to $200 \mathrm{~g}$. The other two groups, obtained from artificial propagation, were differentiated by the diet they had been fed for three months preceding sampling (one diet containing 38\% crude protein, CP, and 3,200 kcal kg estimated metabolizable energy, ME, and other with 34\% CP and 3,650 $\mathrm{kcal} \mathrm{kg}^{-1} \mathrm{ME}$ ). Similar amino acid compositions were obtained for all groups. An estimate of jundiá daily EAA requirements was made using jundiá muscle tissue composition and also taking into account the average EAA requirement for other omnivorous species such as channel catfish (Ictalurus punctatus, Rafinesque, 1818), Nile tilapia (Oreochromis niloticus, Linnaeus, 1758) and common carp (Cyprinus carpio, Linnaeus, 1758). The estimated requirements proposed could help formulating diets for jundiá until dietary EAA dose-response experiments are performed. Key words: nutrition, catfish, siluriformes, growth, weigth gain
\end{abstract}

\section{ESTIMATIVA DA EXIGÊNCIA DIETÉTICA EM AMINOÁCIDOS PARA O JUNDIÁ (Rhamdia quelen) BASEADA NA COMPOSIÇÃO MUSCULAR}

\begin{abstract}
RESUMO: O jundiá, Rhamdia quelen (Quoy \& Gaimard, 1824), é um bagre de ampla ocorrência nas Américas do Sul e Central e atualmente vem sendo criado na Região Sul do Brasil por ser uma espécie de fácil manejo, resistente ao frio e eficiente na conversão de alimento, além de apresentar carne saborosa e sem espinhos intramusculares. Apesar disso, muitas das exigências nutricionais desta espécie ainda não foram investigadas, dentre elas as exigências em aminoácidos essenciais (AAE). Desta maneira, o presente estudo propôs estimar estas exigências em AAE a partir da composição em AAE do tecido muscular desta espécie. Para tanto, foi determinada a composição em aminoácidos do tecido muscular de quatro grupos de jundiá, dois provenientes da natureza, diferenciados por duas faixas de peso (1 a $100 \mathrm{~g}$ e $101 \mathrm{a} 200 \mathrm{~g}$ ), e outros dois provenientes de criações, diferenciados pela dieta a que foram submetidos nos três meses antecedentes à coleta (uma contendo $38 \%$ de proteína bruta, $\mathrm{PB}$, e $3200 \mathrm{kcal} \mathrm{kg}^{-1}$ de energia metabolizável estimada, EM, e outra contendo $34 \%$ $\mathrm{PB}$ e $\left.3650 \mathrm{kcal} \mathrm{kg}^{-1} \mathrm{EM}\right)$. A composição em aminoácidos foi similar entre todos os grupos analisados e, a partir delas, a exigência dietética em cada aminoácido essencial foi estimada levando-se em conta a exigência média de outras espécies onívoras, tais como o bagre do canal (Ictalurus punctatus Rafinesque, 1818), a tilápia nilótica (Oreochromis niloticus, Linnaeus, 1758) e a carpa comum (Cyprinus carpio, Linnaeus, 1758). Até que sejam realizados experimentos de dose-resposta para a determinação das exigências em AAE com o jundiá, sugere-se a utilização da estimativa aqui proposta para auxiliar na formulação de dietas.
\end{abstract}

Palavras-chave: nutrição, bagre, siluriformes, crescimento, ganho em peso

\section{INTRODUCTION}

Protein is the most expensive dietary macronu- trient and directly affects fish weight gain (Page \& Andrews, 1973; Garling \& Wilson, 1976; Sheng \& He, 1994; Ng et al., 2001). However, the balance of the pro-

Sci. Agric. (Piracicaba, Braz.), v.62, n.4, p.401-405, July/Aug. 2005 
tein essential amino acids (EAA) is also fundamental since fish have quantitative requirements for each EAA. Determination of fish amino acid requirements is usually done through dose-response studies, which are costly and time consuming, especially when determining the requirement for all essential amino acids (Akiyama et al., 1997).

Wilson \& Poe (1985) have determined channel catfish (Ictalurus punctatus, Rafinesque, 1818) body amino acid composition and identified a strong correlation $(r=0.96)$ between body amino acid profile and EAA requirements for this species. Based on this concept, estimates of EAA requirements have been calculated for several fish species (Kaushik, 1998; Ngamsnae et al., 1999; Portz, 2001). Because the last method is inexpensive and a fast alternative when compared to amino acid dose-response experiments (Akiyama et al., 1997), it has been recommended for fish species whose EAA requirements have not yet been determined.

Jundiá, Rhamdia quelen (Quoy \& Gaimard, 1824), is an omnivorous freshwater catfish of wide geographic distribution (Silfvergrip, 1996). Because of the species easy handling, high growth rates even during winter, and especially because of its flavorsome meat and absence of intramuscular bones (Fracalossi et al., 2002) there has been a growing interest in farming this species in Southern Brazil. Protein requirement and optimum dietary protein to energy ratios for jundiá have already been studied (Meyer \& Fracalossi, 2004). However, amino acid requirement studies have not yet been carried out for this species. Therefore, the objectives of the present study are determining muscle tissue amino acid compositions of different groups of jundiá, and estimating the EAA requirements by comparing jundiá amino acid body composition with the dietary EAA requirements of other omnivorous fish species.

\section{MATERIAL AND METHODS}

Muscle tissue amino acid compositions of four groups of ten jundiá were analyzed. Two groups were wild caught (Uruguai river basin, $27^{\circ} 08^{\prime} \mathrm{S}$ and $51^{\circ} 03^{\prime} \mathrm{W}$ ) in July 2002 and were classified in the following categories: between 1 and $100 \mathrm{~g}(\mathrm{~N}-100)$ or between 101 and $200 \mathrm{~g}(\mathrm{~N}-200)$. At the same period, the other two groups were sampled from an artificial spawning shoal, also in July 2002, at Florianópolis (27 $37^{\prime}$ S and $48^{\circ} 38^{\prime} \mathrm{W}$ ), Santa Catarina state, and were classified according to the concentration of dietary crude protein (CP) and energy they had been fed for three months preceding sampling. The two categories were: fish previously fed a diet containing $38 \% \mathrm{CP}$ and $3,200 \mathrm{kcal} \mathrm{kg}^{-1}$ (C-38) and fish previously fed a diet containing $34 \%$ and $3,650 \mathrm{kcal} \mathrm{kg}^{-1}$ (C34) (Table 1). Samples of approximately $1 \mathrm{~cm}^{3}$ of hepaxial muscle tissue were collected from all groups, grinded with a food mixer, pooled, and frozen $\left(-20^{\circ} \mathrm{C}\right)$ for later determination of amino acid composition.

The muscle protein content was determined using the Kjeldahl method $(\mathrm{N} \times 6.25)$, after acid digestion, following AOAC (1999) procedures. Amino acid concentrations were determined using the methodology proposed by Spitz (1973), except for methionine and cystine (Llames \& Fontaine, 1994). Additionally, the $\mathrm{A} / \mathrm{E}$ ratio (essential amino acid / total essential amino acids $\times 1,000$ ) was calculated to compare jundiá muscle tissue amino acid profile to those from other fish species.

\section{RESULTS AND DISCUSSION}

Table 2 shows the amino acid composition of muscle tissue determined for all groups. Great similarity among the amino acid composition of all groups, either from the wild or from artificial spawning was observed. Therefore, EAA concentration in jundiá muscle tissue did not depend on fish weight or dietary history.

The amino acid composition of jundiá, expressed as $\mathrm{A} / \mathrm{E}$ ratio (essential amino acid / total of essential amino acids $\times 1,000)$, is similar to that obtained for other fish species, except for tryptophan and methionine+cystine (Table 3). Although reasons for this discrepancy re-

Table 1 - Groups of jundiá used to determine muscle tissue amino acid composition.

\begin{tabular}{|c|c|c|c|c|}
\hline Group & Weight class & Sampling location & Previous diet & $\begin{array}{l}\text { Number of } \\
\text { fish sampled }\end{array}$ \\
\hline & $\mathrm{g}$ & & & \\
\hline N-100 & $1-100$ & Uruguay River $^{\mathrm{a}}$ & Natural $^{c}$ & 10 \\
\hline N-200 & $101-200$ & Uruguay River & Natural & 10 \\
\hline C-34 & 10 & Artificial spawning, Florianópolis ${ }^{\mathrm{b}}$ & Semipurified containing $34 \% \mathrm{CP}$ and $3650 \mathrm{kcal} \mathrm{ME}$ & 10 \\
\hline $\mathrm{C}-38$ & 10 & Artificial spawning, Florianópolis & Semipurified containing $38 \% \mathrm{CP}$ and $3200 \mathrm{kcal} \mathrm{ME}^{\mathrm{d}}$ & 10 \\
\hline
\end{tabular}

${ }^{\mathrm{a}} 27^{\circ} 08^{\prime} \mathrm{S}$ and $51^{\circ} 03^{\prime} \mathrm{W}$; ${ }^{\mathrm{b}} 27^{\circ} 37^{\prime} \mathrm{S}$ and $48^{\circ} 38^{\prime} \mathrm{W}$; ' Analysis of stomach content of this species has shown the following composition: fish $(46 \%)$, crustaceans $(20 \%)$, insects $(19 \%)$, sediments $(4 \%)$, vegetable remains $(6 \%)$, annelids $(2 \%)$, and other food items $(3 \%)$ (Meurer \& Zaniboni Filho, 1997); ${ }^{\mathrm{d}} \mathrm{CP}=$ Crude Protein, $\mathrm{ME}=$ estimated metabolizable energy, calculated from physiological standard values, where $1 \mathrm{~g}$ of carbohydrate, protein and lipid yield 4, 4, and $9 \mathrm{kcal}$, respectively (Lee \& Putnam, 1973). 
main unknown, results agree with findings of Wilson (1989), who reported similarities among the amino acid profile of different fish species, except for tryptophan and methionine+cystine.
Among the techniques used to determine amino acid requirement of fish species, the one relating the body amino acid composition to dietary lysine requirement, measured through dose-response experiments, seems to

Table 2 - Amino acid composition of four different groups of jundiá, Rhamdia quelen.

\begin{tabular}{|c|c|c|c|c|c|c|}
\hline \multirow{2}{*}{ Amino acid } & \multicolumn{6}{|c|}{ Composition (\% protein) } \\
\hline & $C-34^{a}$ & $\mathrm{C}-38^{\mathrm{b}}$ & $\mathrm{N}-100^{\mathrm{c}}$ & $\mathrm{N}-200^{\mathrm{d}}$ & Mean & Standard deviation \\
\hline \multicolumn{7}{|l|}{ Essential } \\
\hline Arginine & 6.16 & 6.16 & 6.29 & 6.07 & 6.17 & 0.09 \\
\hline Histidine & 2.16 & 2.31 & 2.12 & 2.12 & 2.18 & 0.09 \\
\hline Isoleucine & 4.20 & 4.22 & 4.23 & 4.19 & 4.21 & 0.02 \\
\hline Leucine & 8.40 & 8.43 & 8.17 & 8.35 & 8.34 & 0.11 \\
\hline Lysine & 9.62 & 9.68 & 9.48 & 9.75 & 9.63 & 0.12 \\
\hline Methionine & 3.45 & 3.42 & 3.42 & 3.83 & 3.53 & 0.20 \\
\hline Phenylalanine & 4.40 & 4.44 & 4.40 & 4.62 & 4.47 & 0.11 \\
\hline Threonine & 4.99 & 5.03 & 4.94 & 4.95 & 4.98 & 0.04 \\
\hline Tryptophan & 0.43 & 0.46 & 0.47 & 0.45 & 0.45 & 0.01 \\
\hline Valine & 4.42 & 4.43 & 4.36 & 4.40 & 4.40 & 0.03 \\
\hline Total EAA ${ }^{\mathrm{e}}$ & 48.23 & 48.57 & 47.87 & 48.74 & 48.35 & 0.38 \\
\hline \multicolumn{7}{|l|}{ Non-Essential } \\
\hline Serine & 4.59 & 4.58 & 4.59 & 4.51 & 4.59 & 0.04 \\
\hline Glutamic acid & 16.92 & 16.93 & 16.70 & 16.71 & 16.92 & 0.13 \\
\hline Aspartic acid & 10.94 & 10.99 & 10.92 & 11.10 & 10.94 & 0.07 \\
\hline Proline & 3.47 & 3.24 & 3.31 & 3.23 & 3.47 & 0.11 \\
\hline Glycine & 4.79 & 4.69 & 5.63 & 4.58 & 4.79 & 0.47 \\
\hline Alanine & 5.95 & 5.94 & 6.12 & 5.90 & 5.94 & 0.10 \\
\hline Cystine & 1.62 & 1.54 & 1.53 & 1.77 & 1.62 & 0.11 \\
\hline Tyrosine & 3.48 & 3.50 & 3.32 & 3.47 & 3.48 & 0.08 \\
\hline
\end{tabular}

a Fish fed diets containing $34 \%$ of crude protein and $3,650 \mathrm{kcal} \mathrm{kg}^{-1}$ of estimated metabolizable energy, during the three months preceding the analyses; ${ }^{b}$ Fish fed diets containing $38 \%$ crude protein and 3,200 kcal kg-1 of estimated metabolizable energy, during the three months preceding the analyses; ${ }^{\circ}$ Fish sampled in the wild weighing between 1 and $100 \mathrm{~g}$; ${ }^{\mathrm{d}}$ Fish sampled in the wild weighing between 101 and 200 g; ${ }^{e}$ Essential amino acids.

Table 3 - A/E ratios (essential amino acid / total essential amino acids $\times 1,000)$ of jundiá muscle tissue and of other omnivorous and carnivorous fish species.

\begin{tabular}{|c|c|c|c|c|c|c|c|}
\hline \multirow{3}{*}{ Amino acid } & \multicolumn{7}{|c|}{$\mathrm{A} / \mathrm{E}$ ratios } \\
\hline & \multicolumn{3}{|c|}{ Omnivorous } & \multicolumn{4}{|c|}{ Carnivorous } \\
\hline & Jundiáa $^{a}$ & Channel catfish ${ }^{\mathrm{b}, \mathrm{c}}$ & Nile tilapia ${ }^{a, d}$ & Pintado ${ }^{a, d}$ & Black bass ${ }^{\mathrm{a}, \mathrm{d}}$ & Rainbow trout ${ }^{\mathrm{b}, \mathrm{e}}$ & Atlantic salmon ${ }^{\mathrm{b}, \mathrm{e}}$ \\
\hline Arginine & 115.5 & 132.0 & 142.0 & 133.0 & 132.0 & 125.5 & 123.3 \\
\hline Histidine & 40.8 & 43.0 & 44.0 & 58.7 & 44.8 & 57.4 & 56.9 \\
\hline Isoleucine & 78.8 & 85.0 & 93.6 & 82.5 & 75.4 & 83.8 & 83.4 \\
\hline Leucine & 156.1 & 146.0 & 160.0 & 154.0 & 150.9 & 146.6 & 145.9 \\
\hline Lysine & 180.2 & 168.0 & 160.2 & 166.2 & 177.8 & 176.3 & 163.2 \\
\hline Met+Cys & 96.4 & 75.0 & 72.1 & 69.3 & 79.1 & 52.8 & 70.8 \\
\hline Phe+Tyr & 148.3 & 147.0 & 129.2 & 139.9 & 148.0 & 149.3 & 149.2 \\
\hline Threonine & 93.2 & 87.0 & 89.3 & 91.7 & 90.9 & 94.0 & 91.5 \\
\hline Tryptophan & 8.4 & 15.0 & 18.3 & 18.1 & 17.8 & 17.7 & 17.9 \\
\hline Valine & 82.4 & 102.0 & 91.3 & 86.6 & 83.3 & 96.7 & 97.9 \\
\hline
\end{tabular}

a Muscle tissue composition; ${ }^{\mathrm{b}}$ Whole body composition; ${ }^{\mathrm{c} W}$ Wilson \& Poe, 1985; ${ }^{\mathrm{d}}$ Portz, 2001; ${ }^{\mathrm{e} W i l s o n}$ \& Cowey, 1985. 
Table 4 - Amino acid requirements for channel catfish (Ictalurus punctatus), Nile tilapia (Oreochromis niloticus) and common carp (Cyprinus carpio), and estimated amino acid requirements for jundiá (Rhamdia quelen). ${ }^{\mathrm{a}}$

\begin{tabular}{|c|c|c|c|c|c|}
\hline \multirow{2}{*}{ Amino acid } & \multicolumn{3}{|c|}{ Requirements ${ }^{\mathrm{b}}$} & \multirow{2}{*}{$\begin{array}{l}\text { Average jundiá muscle tissue } \\
\text { composition }\end{array}$} & \multirow{2}{*}{$\begin{array}{l}\text { Jundiá estimated } \\
\text { requirement }{ }^{i}\end{array}$} \\
\hline & Channel catfish ${ }^{\mathrm{c}}$ & Nile tilapia $^{\mathrm{d}}$ & Common carp ${ }^{\mathrm{c}}$ & & \\
\hline \multicolumn{6}{|c|}{ (\% dietary protein) } \\
\hline Arginine & 4.30 & 4.20 & 4.30 & 6.17 & 3.72 \\
\hline Histidine & 1.50 & 1.72 & 2.10 & 2.18 & 1.31 \\
\hline Isoleucine & 2.60 & 3.11 & 2.50 & 4.21 & 2.54 \\
\hline Leucine & 3.50 & 3.39 & 3.30 & 8.34 & 5.03 \\
\hline Lysine & 5.10 & 5.12 & 5.70 & 9.63 & 5.80 \\
\hline Methionine & 2.30 & 2.68 & 2.10 & 3.53 & 2.13 \\
\hline Cystine $^{e}$ & 0.00 & 0.54 & 0.00 & 1.62 & 0.98 \\
\hline Phenylalanine & 5.00 & 3.75 & 3.40 & 4.47 & 2.69 \\
\hline Tyrosine $e^{f}$ & 0.30 & 1.79 & 1.00 & 3.48 & 2.10 \\
\hline Threonine & 2.00 & 3.75 & 3.90 & 4.98 & 3.00 \\
\hline Tryptophan & 0.50 & 1.00 & 3.60 & 0.45 & 0.27 \\
\hline Valine & 3.00 & 2.80 & 0.80 & 4.40 & 2.65 \\
\hline TEAA $^{\mathrm{g}}$ & 30.10 & 33.85 & 32.70 & 53.46 & 32.22 \\
\hline Mean $^{\mathrm{h}}$ & & 32.22 & & & \\
\hline
\end{tabular}

${ }^{a}$ Essential amino acid requirement $=[$ (amount of this amino acid in the jundiá muscle tissue $) \times($ average TEAA requirement among channel catfish, Nile tilapia and common carp)] / (average jundiá muscle TEAA); 'betermined through dose-response experiments; 'NRC, 1993; 'Santiago \& Lovell, 1988; 'Non-essential amino acid, capable of sparing dietary methionine (Moon \& Gatlin, 1990); ${ }^{\mathrm{f}}$ Nonessential amino acid, capable of sparing dietary phenylalanine (Wilson, 1989); ${ }^{\text {g}}$ Total essential amino acids.

be the fastest and the most cost efficient. Kaushik (1998) has estimated the EAA requirements for gilthead seabream using this methodology. The estimates were obtained using the following formula: essential amino acid requirement $=($ amount of the specific EAA $\times$ dietary lysine requirement) / amount of body lysine. Similarly, Ngamsnae et al. (1999) estimated the EAA requirements for silver perch, Bidyanus bidyanus (Mitchell, 1838). However, this later study used the requirements for phenylalanine and arginine, instead of lysine, determined through dose-response experiments. No EAA requirement study has yet been carried out for jundiá, thus preventing the estimate through this methodology. On the other hand, there is a great similarity in the EAA total requirement among several freshwater omnivorous fish species, bearing feeding habits similar to that of the jundiá (Table 4). For that reason, the total essential amino acid (TEAA) average among channel catfish, Nile tilapia and common carp, combined to the EAA muscle tissue composition of jundiá, were used in estimating EAA requirements for this species. Estimated values (Table 4) have been obtained using a formula similar to that described by Kaushik (1998): essential amino acid requirement $=[$ (amount of an individual amino acid in jundiá muscle tissue) $\times$ (average TEAA requirement among channel catfish, Nile tilapia and common carp)] / (average jundiá muscle TEAA).

Tryptophan is largely required for synthesis of other compounds besides muscle protein (NRC, 1993).
Therefore, requirements presented in Table 4 are probably underestimated. The cystine and tyrosine supplied in the diet can only spare around $50 \%$ of the methionine and phenylalanine requirements, respectively (NRC, 1993), and these values were not yet investigated for jundiá. Thus, the methionine and phenylalanine requirements estimated in this study are presented apart from those estimated for cystine and tyrosine, unlike some other studies, where they are presented as requirements for methionine + cystine and phenylalanine + tyrosine (Kaushik, 1998; Moon \& Gatlin III, 1990; Ngamsnae et al., 1999). Additionally, studies testing dietary lysine requirements of jundiá should be carried out to confirm the estimated requirements herein presented. Until doseresponse experiments have been carried out to precisely determine EAA requirements for the species, the estimated values proposed in this study could be used when formulating diets for jundiá.

\section{ACKNOWLEDGEMENTS}

The authors wish to thank Tractebel Energia for the financial support, the National Center for Swine and Poultry Research (CNPSA / EMBRAPA) for their assistance in the amino acid analyses, and the Coordination for Improvement of Higher Education Personnel (CAPES) for providing a Master's fellowship to the first author. 


\section{REFERENCES}

AKIYAMA, T.; OOHARA, I.; YAMAMOTO, T. Comparison of essential amino acid requirement with $\mathrm{A} / \mathrm{E}$ ratio among fish species (Review Paper). Fisheries Science, v.63, p.963-970, 1997.

ASSOCIATION OF OFFICIAL ANALITYCAL CHEMISTS. Official methods of analysis of the AOAC. 16.ed. Washington: AOAC International, 1999. 1141p.

FRACALOSSI, D.M.; ZANIBONI FILHO, E.; MEURER, S. No rastro das espécies nativas. Panorama da Aqüicultura, v.12, p.43-49, 2002.

GARLING, D.L.; WILSON, R.P. Optimum dietary protein to energy ratios for channel catfish fingerlings, Ictalurus punctatus. Journal of Nutrition, v.106, p.1368-1375, 1976

KAUSHIK, S.J. Whole body amino acid composition of European seabass (Dicentrarchus labrax), gilthhead seabream (Sparus aurata) and turbot (Psetta maxima) with an estimation of their IAA requirement profiles. Aquatic Living Resources, v.11, p.355-358, 1998.

LEE, D.J.; PUTNAM, G.B. The response of rainbow trout to varying protein / energy ratios in a test diet. Journal of Nutrition, v.103, p.916-922, 1973.

LLAMES, C.R.; FONTAINE, J. Determination of amino acid in feeds: colaborative study. Journal of AOAC International, v.77, p.1362-1402, 1994.

MEURER, S.; ZANIBONI FILHO, E. Hábito alimentar do jundiá, Rhamdia quelen (Pisces, Siluriformes, Pimelodidae), na região do alto rio Uruguai. In: ENCONTRO BRASILEIRO DE ICTIOLOGIA, 12., São Paulo, 1997. Anais. São Paulo: SBI, 1997. p.29.

MEYER, G.; FRACALOSSI, D.M. Protein requirement of jundiá fingerlings, Rhamdia quelen, at two dietary energy concentrations. Aquaculture, v.240, p.331-343, 2004.

MOON, H.Y.; GATLIN III, D.M. Total sulfur amino acid requirement of juvenile red drum, Sciaenops ocellatus. Aquaculture, v.95, p.97-106, 1990.

NATIONAL RESEARCH COUNCIL - NRC. Nutrient requirements of fish. Washington: National Academic Press, 1993. 114p.

NG, W.K.; SOON, S.C.; HASHIM, R. The dietary requirement of bagrid catfish, Mystus nemurus (Cuvier \& Valenciennes), determined using semipurified diets of varying protein level. Aquaculture Nutrition, v.7, p.45-51, 2001
NGAMSNAE, P.; DE SILVA, S.S.; GUNASEKERA, R.M. Arginine and phenylalanine requirement of juvenile silver perch Bydianus bydianus and validation of the use of body amino acid composition for estimating individual amino acid requirement. Aquaculture Nutrition, v.5, p.173$180,1999$.

PAGE, J.W.; ANDREWS, J.W. Interactions of dietary levels of protein and energy on channel catfish (Ictalurus punctatus). Journal of Nutrition, v.103, p.339-1346, 1973.

PORTZ, L. Utilização de diferentes fontes protéicas em dietas formuladas pelo conceito de proteína ideal para o "black bass" (Micropterus salmoides). Piracicaba: USP/ESALQ, 2001. 111p. (Tese - Doutorado).

SANTIAGO, C.B.; LOVELL, R.T. Amino acid requirement for growth of Nile tilapia. Journal of Nutrition, v.118, p.1540-1546, 1988.

SHENG, H.Q.; HE, X.Q. Effects of dietary animal and plant protein ratios and energy levels on growth and body composition of bream (Megalobrama skolkovii) fingerlings. Aquaculture, v.127, p.189-196, 1994

SILFVERGRIP, A.M.C. A systematic revision of the neotropical catfish genus Rhamdia (Teleostei, Pimelodidae). Stocolm: Swedish Museum of Natural History, Department of Vertebrate Zoology, 1996. 156p. (Doctor Thesis).

SPITZ, H.D. Amino acid determination - hydrolysis procedure. Analytical Biochemistry, v.56, p.66-73, 1973.

WILSON, R.P. Amino acids and proteins. In: HALVER, J.E. Fish nutrition. 2.ed. New York: Academic Press, 1989. p.112-151.

WILSON, R.P.; COWEY, C.B. Amino acid composition of whole body tissue of rainbow trout and Atlantic salmon. Aquaculture, v.48, p.373-376, 1985

WILSON, R.P.; POE, W.E. Relationship of whole body and egg essential amino acid patterns to amino acid requirement patterns in channel catfish, Ictalurus punctatus. Comparative Biochemistry and Physiology, v.80B, p.385-388, 1985.

Received July 13, 2004

Accepted May 05, 2005 